\title{
Where are all the students? Demobilisation and re- engagement in higher education in Turkey and beyond
}

\section{Jordi Tejel Gorgas}

Translator. Liath Gleeson

\section{OpenEdition \\ Journals}

Electronic version

URL: http://journals.openedition.org/ejts/6855

DOI: $10.4000 /$ ejts. 6855

ISSN: $1773-0546$

Publisher

EJTS

\section{Electronic reference}

Jordi Tejel Gorgas, "Where are all the students? Demobilisation and re-engagement in higher education in Turkey and beyond", European Journal of Turkish Studies [Online], 17 | 2013, Online since 15 February 2020, connection on 04 February 2021. URL: http://journals.openedition.org/ejts/6855; DOl: https://doi.org/10.4000/ejts.6855

This text was automatically generated on 4 February 2021.

(c) Some rights reserved / Creative Commons license 


\title{
Where are all the students? Demobilisation and re-engagement in higher education in Turkey and beyond
}

\author{
Jordi Tejel Gorgas \\ Translation : Liath Gleeson
}

\section{AUTHOR'S NOTE}

I wish to thank the Swiss National Science Foundation for the financial support that allowed me to complete my research project, "States, Minorities and Conflicts in the Middle East (1948-2003)", conducted between 2010-2014 at the Graduate Institute of International and Development Studies, Geneva. This issue is one of the most valuable outcomes of that project. However, it goes without saying that the opinions expressed here belong to no one but the author.

1 When the mass demonstrations against the Turkish government's development projects in Gezi Park took place between late May and mid-June of 2013, I was in Istanbul, conducting interviews for my own research about the student movements of the 1960s-1980s in Turkey. Although the Istanbul-based movement was outside my sphere of interest, ${ }^{1}$ I couldn't help swapping roles from 'historian' to 'anthropologist' and making regular visits to Gezi Park to observe, in situ, western Turkey's largest protest movement of the last twenty years. After two weeks going back and forth and several discussions with protestors, as well as with participants in the student demonstrations of the 1960s-1980s, several observations are I think directly linked to the subject of this issue of the European Journal of Turkish Studies.

2 Firstly, the Gezi Park movement was both leaderless and extremely heterogeneous, encompassing a wide variety of groups (environmentalists, students, defenders of 
LGBTQ and women's rights, etc.) and a broad spectrum of political leanings, ranging from far left to far right by way of Kemalist-adjacent groups, Islamists and Kurdish nationalists. ${ }^{2}$ Alongside groups representing 'civil society' and political, trade-union and professional organisations were a significant number of protesters with no affiliation, a fact borne out by the results of the first survey conducted during the protests. Between June 3 and 4, 2013, Esra Ercan Bilgiç and Zehra Kafkasli, lecturers at Bilgi University (Istanbul), organised a survey of 3,000 protesters gathered between Gezi Park and Taksim Square. According to the interviews carried out, $70 \%$ of protest participants claimed not to be affiliated with any political party, the majority identifying as 'libertarians' (özgürlükçü), while only $7.7 \%$ claimed they had come to Taksim square at the encouragement of an organisation, even though more than half of those surveyed also did not consider themselves 'apolitical'. Finally, $53.7 \%$ of those interviewed stated that this was their first time taking part in a street protest. ${ }^{3}$

3 Secondly, a large number of the protesters not affiliated with any party or organisation were predominantly young - a fact again confirmed by the aforementioned survey ( $40 \%$ between 19-25 years, $24 \%$ between 26-30 years) -, students of higher education, middle class, secular - although there were a noticeable number of (anti-capitalist and feminist) 'Muslim' groups - and very plugged into social media. However, their identity as students did not seem to be the determining factor in this context, as the majority of protesters had not tried to rally around the few student organisations present at Gezi, but had come Taksim Square 'spontaneously'.

4 Finally, the university professors interviewed in Istanbul expressed surprise at this sudden mobilisation, in the mould of the revolts seen in the Arab world between 2010-2011. By their accounts, nothing could have predicted the significant role their students would play in the Gezi movement. Demonstrations on university grounds were almost non-existent in the months prior, and support for student unions was at an alltime low. And yet, the number of third-level students at Gezi was so high that some university directors eventually proposed extending the end of year exam period, despite pressure from YÖK (the Board of Higher Education) and the Turkish government.

5 In addition, and in step with most of the Arab countries that have seen popular uprisings since 2010, a "minor" event involving some slightly over-zealous security forces appears to have driven thousands of people to occupy a defined urban space (Taksim Square and Gezi Park) - a zone now considered "free" and "protected" - and contributed to an "expedited" process of socialisation and politicisation. (Fillieule, 2013; 287-308). Despite the violent evacuation of protesters from Gezi on June 15, the experience of 'occupying' Istanbul and other Turkish cities that expressed their solidarity with the movement marked, for some, the start of a new era in Turkish politics; the end of a long 'cycle of demobilisation'.

6 The intention here is not to analyse these 'events' in the purely semantic sense of the term, ${ }^{4}$ nor to take a position in the debate over the end (or not) of the 'cycle of demobilisation' in Turkey and the Middle-East more generally. We propose a different focus, one which draws from two sources. Acknowledging the mass demonstrations around Gezi Park and their ramifications across Turkey (Bilgin, 2013; Gökay and Xypolia, 2013; Kongar and Küçükkaya, 2013; Özbank, 2013, Yıldırım, 2013) while also heeding the call of Olivier Fillieule and other researchers to further examine the phenomenon of activist defection (Filleule, 2005; Fuchs-Ebaugh, 1988; Björgo and 
Horgan, 2009), this issue aims to scrutinise some of the dominant paradigms surrounding core issues that remain under-investigated in the study of collective action; namely, its decline, and in particular, questions relating to individual disengagement and collective mobilisation.

7 To do this, the contributions included in this special issue, which are drawn from various disciplines (history, political science, sociology), address a range of different territories (from Turkey to Mexico by way of Egypt and Morocco) and are cognisant of early analyses of individual disengagement in countries where mass demonstrations have recently occurred (Egypt and Morocco), are focused on a specific social group: students of higher-level education. Students were considered the leaders of social change in the years after the Second World War, particularly in developing countries. However, while students of higher education are the starting point for all the articles included in this issue, several authors have also added a minor or major focus on other important actors in the university sphere.

8 Student movements certainly do not occur in isolation; they are positioned in interrelation with numerous actors belonging not only to the sphere of higher education (coordinating bodies of higher-level institutions, professors, deans, chancellors, lecturers) but also with other categories that must be taken into consideration ('Foyers Idéalistes' [Trans. note: Ülkü Ocakları, a Turkish ultranationalist militant group], intellectuals, political parties, second-level schools, security forces, etc). Accordingly, some submissions have tackled the challenge of studying the phenomenon of individual disengagement among higher education students from a process- and/or relation-based perspective, incorporating both long-term developments and actors who, as part of their mission, have decisively impacted both mobilisation and disengagement among the student population.

9 Naturally, the issue contains a number of blind spots, such as examining the phenomenon of individual disengagement within Islamist-oriented political movements. Furthermore, future analyses rooted firmly in a comparative approach should help advance our understanding of an issue that remains largely neglected within research on social mobilisation.

\section{The "front line" of the nation}

10 Our interest in students of higher education has multiple roots. The Middle-East has a tradition of mass student demonstrations, going back to at least the early 20th century. The considerable engagement of students in secondary schools and on university campuses, as well as in national-level political debates, made them a true social and symbolic force within the Arab world (Abdalla, 1985; Haggai, 1989; Bashkin, 2009; Watenpaugh, 2002: 325-347) in the fight against colonialism. The expansion of compulsory education and universities from the $1950 \mathrm{~s}$ on, as well as the 'modernisation' projects of the new state elites, only strengthened the student position at the forefront of the region's society and politics. In the process, the universities and colleges of the post-colonial era inherited a dual role: "servant of the State and crucible for nation-building" [Trans. note: "service de l'État et creuset de la construction nationale"] (Rey, 2010: 29). ${ }^{5}$

11 However, the opening up of colleges and universities, previously characterised by a certain elitism, to a greater number of students lead to a series of significant socio- 
political transformations throughout the 1960s-1970s: ${ }^{6}$ the spectrum of students' social, ethnic and religious backgrounds broadened considerably; a process of massification occurred in some universities, provoking tension around the resources allocated to education; and finally, the emergence of 'students' as a distinct social group, which translated into the first state political initiatives aimed specifically at the 'youth' - still thought of primarily as the 'educated and urban youth" ${ }^{1}$ - with the creation of the ministries of youth and education in the 1970s-1980s.

In many Arab countries faced with the accelerating disappearance of pluralism and freedom of expression in the political sphere, from Tunisia to Iraq by way of Egypt, the university became, a "substitute political arena" [Trans. note: "champ politique de substitution"] to varying degrees, as well as a vessel for the "hopes, frustrations and demands" [Trans. note: "aspirations, des frustrations et des revendications"] (Guiter, 1997: 93) of Arab societies in a post-colonial environment. During the 1960-1980s, university students positioned themselves at the spearhead of societal debates, particularly (in both a metaphorical and a literal sense) in the clashes between the various political currents dominating the Middle-East as a region: communism, Pan-Arabism, Arabic socialism and Islamism.

Turkey, having never experienced colonialism, followed a unique path of development in the first half of the 20th century. As a result, unlike in the majority of Arab nations, Turkish universities remained outside the sphere of colonial influence. Under the Republic of 1923, higher education was seen by the modern elites as a key tool for modernising Turkish society and creating "True Turks" (öz Türkler) loyal to the Turkish republic. While all groups in Turkish society had some responsibility in the task of modernising Turkey, the (educated) 'youth' had a special role to play. In his famous Speech (Nutuk) delivered in October 1927, Mustafa Kemal sacrilised the task bestowed on the youth by the State: "Oh, Turkish youth, we have built the Republic; it is up to you breathe life into it and allow it to grow" [Trans. note: "Ô jeunesse turque, nous avons bâti la République, c'est à vous de la faire vivre et de lui permettre de s'élever"] (Kemal, 1989: 1197). This has been noted by Leyla Neyzi, among other authors (Neyzi, 2001: 411-432: Lüküslü, 2005: 31-32). However, the conception of 'youth' presented in Kemalist discourse was a construction of the state; in other words: "The youth received this mission, they did not choose it for themselves" [Trans. note: "la jeunesse reçoit cette mission, elle ne se l'octroie pas"] (şeni, 2007: 241).

There were dedicated national youth holidays, and attention was paid to education. From 1924 onwards, the law for the unification of education placed all educational institutions under the control of the national Ministry of Education. Additionally, all religious schools were closed. The majority of university graduates was recruited straight into the civil service, leaving the private sector of the economy "abandoned" [Trans. note: "orphelin"] (Aypay, 2003: 109-135). In 1937, the Reorganisation Law decided on the closure of the first Ottoman university - Darülfünün (1863) - in order to make way for Istanbul University. The universities act of 1946 granted complete autonomy to centres of higher education, and between 1956 and 1960, the number of university students grew from 20,000 to 65,0000 (Szyliowicz, 1973: 417).

Certain tensions regarding the resources allocated to universities notwithstanding, the student body, in contrast to the Arab countries, did not establish itself as a force for protest. This was because, as we have seen, students were ideologically locked into defending the values of a republic which happened not to have experienced colonial 
influence. The reality was that the majority of student organisations of this period, contrary to certain preconceived notions that too often label student movements as exclusively left-wing, were positioned firmly on the right of the political chessboard, their sole credo being Atatürkist nationalism.

After the Second World War, however, Turkey's path of development was comparable to that of the other Middle-Eastern countries. As such, in 1946, the university system became one of the core points of debate in Turkish politics due to the simultaneous introduction of both political pluralism and the law on the autonomy of universities (Turan, 2010: 142-164). In addition, attempting to meet the pressing demands of a rapidly growing youth that had its sights set on becoming a key actor in the nation's economic and political structures, the Turkish state supported the construction of new universities across the country. Thus, between 1957 and 1977, the number of Turkish universities grew from six to seventeen, while the number of students went from 65,000 to 340,000 (Ozankaya, 1978).

These developments, concurrent with the events of history both international (the Cold War, the Cyprus Crisis, increased internationalisation of the Turkish economy, reinforcement of America's presence in the region) and domestic (rapid urbanisation, social tension and proletarianisation of the economy, growing tensions between the Kemalist left and the conservative right, military interventionism in the country's politics), propelled vast numbers of high school and university students to the centre of Turkey's social and political stage. (Alper, 2010). Universities, as "hosts to these processes of polarisation and escalating violence, consequently became sites of politicisation of the individual" [Trans. note: traversées par ces processus de polarisation et de montée de violence, deviennent alors des sites de politisation des individus"] (Gourisse, 2010: 362).

18 However, it is worth paying special attention to the role played by university students over these two decades for a number of other reasons. First, the 'alliance' forged between university students and professors, leftist intellectuals and the 'progressivist' factions of the army that laid the groundwork for the coup d'état of May 27, 1960 cemented higher-level students into a central role in the Turkish activist sphere from that point on (Mutlu Ulus, 2011); students considered themselves to have a moral duty and felt unable to simply turn their back on their 'responsibilities'. This alliance also paved the way for a partial liberalisation of the country's political and social arenas, as well as for the expansion of leftist forces from across the entire spectrum within trade unions, politics and student circles (Abadan, 1963; Aydınoğlu, 2011). Furthermore, the participation of university students in the demonstrations that led to the military coup d'état of May 27, 1960 left a deep impression on the "generation of '68" (Monceau, 2007: 97-130), which hoped in vain for an adapted broad alliance of the 'progressivist' groups that would bring about the 'socialist revolution' in Turkey.

19 Second, higher-level students played a major role in the politicisation of "young wolves" in high schools of big cities like Istanbul and Ankara. Accounts by former activists provide evidence that university activists oversaw certain activities by the secondary school students - sit-ins, marches, acts of sabotage - provided written propaganda - brochures, flyers - to their youngest acolytes and sometimes physically protected if they felt threatened by their "enemies" on their way home from school (Mardin, 1977: 229-254). ${ }^{8}$ Their knowledge of the "terrain" let them quickly rebuild trust with old followers, who had since become ringleaders inside the secondary 
schools, thus demonstrating the importance of the self-perpetuation dynamic for politicisation within the student circle (Crossley, 2008: 19-38). In this way, the youngest university activists became the critical link to achieving coordination between high schools and universities, and ultimately, to coordinating the mass student demonstrations of the 1960-1970s. ${ }^{9}$

Third, "revolutionary passions" (Bozarslan, Bataillon and Jaffrelot, 2011), with its attending urban violence, struck university students first. Little by little, clashes on campus and in the streets between far left and far right (the 'Grey Wolves') activists became interspersed with other, more violent actions. From 1970 onwards, some radical-leftist groups shifted to urban guerrilla warfare in order to hasten the 'revolution'. While the coup d'état of 1971 put a temporary halt to student activities, the repression aimed primarily at leftist organisations and the execution of university leaders such as Deniz Gezmiş in 1972 had a counter-productive effect; they created 'youth' icons, 'heroes' fighting for the 'resistance' against 'imperialism' and 'fascism'. ${ }^{10}$ Paradoxically, but in line with an approach similar to that of the extreme left in Japan, Italy and Germany, the radicalisation of certain student organisations led to the leftwing forces becoming progressively marginalised, weakened both by successive divisions and repression by a state apparatus that was increasingly establishing itself as a "fragmented tyranny" [Trans. note: "tyrannie fragmentée"] (Tilly, 2003).

21 Finally, alongside this last point, examining the university student community allows for up-close examination of both the new techniques of repression applied by the Turkish state (and elsewhere in the Middle East), intended to depoliticise a 'youth' that had become a threat to social order, and the new forms of re-engagement that arose in an environment seemingly marked by social demobilisation. In practice, the coup d'état of September 12, 1980 dealt a fatal blow to the 'revolutionary left' and associated movements, while right-wing organisations were targeted less by the punitive measures. Intellectuals, student leaders and grassroots activists were detained, tortured and, in some cases, condemned to exile. The tally of the military putsch 650,000 arrests, 1,683,000 judicial investigations, 517 death sentences ( 49 of which were carried out), 30,000 public service employees dismissed, 667 organisations and foundations banned, hundreds of suspicious deaths - is unequivocal (Massicard, 2010: 6; Duclert, 2010: 32).

At the same time, the state was developing insidious techniques to depoliticise Turkish society, particularly the student sphere. This led to YÖK becoming one of the cornerstones of the university 'normalisation' policy. Founded in November 1981 under law No. 2547 on higher education, the organisation was central to the depoliticisation and, ultimately, the collective demobilisation of university students, as described in Murat Yilmaz's contribution to this issue. New administrative regulations, stripping universities of their autonomy and the surveillance of students and teachers were used to 'pacify' campuses, while a military-neoliberal coalition allowed a partial implementation of the Turko-Islamic synthesis ${ }^{11}$ in universities (Ateş, 1984; Dinç, 1986; şimşek, 2006).

Paradoxically, despite the reforms introduced by successive governments to try and fit Turkey to meet the European Union's requirements regarding YÖK and face the criticisms levelled against it by numerous intellectuals (and even the majority of parties sitting in government), this embarrassing (to say the least) relic of the military intervention of 1980 has been neither abolished nor significantly reformed, thanks to 
the political stranglehold it provides over the university system - something that no party in power has been prepared to sacrifice (Monceau, 2005: 129-142; Y1lmaz, 2012: 153-168).

\section{On the "cycle of demobilisation"}

Collective demobilisation and disengagement are seen by researchers as social and individual processes that encompass a range of phenomena: from the almost total political demobilisation of a society to activist individuals retreating into the private sphere or "exiting" (Hirschman, 1983). In truth, however, beneath this individual and/ or collective retreat lie much more complex social dynamics.

In his very thought-provoking work of synthesis, Sociologie politique du Moyen-Orient (2010), Hamit Bozarslan highlights a fundamental contradiction that researchers - be they historians, political scientists or sociologists - must consider when studying the countries of the Middle East. While on the macro level, we see a "glaring [...] absence of collective action" [Trans. note: "faiblesse [...] criante de l'action collective"] between 1980 and 2010 (with a few exceptions), the micro level reveals "a myriad of actions and acts of resistance" [Trans. note: "myriade d'engagements et d'actes de resistance"] (Bozarslan, 2010: 65). In this regard, the author points to the need to consider not only the processes of demobilisation which have been at work for decades in some countries, but also the reach of quotidian collective actions; the "everyday forms of resistance" beloved of James C. Scott $(1985 ; 1990)$, the "bottom-up politics" elevated in the works of Jean-François Bayart (2008) or the cumulative practices of "non-movements", a concept put forward more recently by Asef Bayat (Bayat, 2010).

While this contradiction is still relevant, Bozarslan makes the deliberate choice not to turn to the sociology of social movements and collective action, a field too often mired in "somewhat abstract modelling practices" [Trans. note: "modélisations quelque peu abstraites"]. Instead, he takes an approach grounded in historical sociology, in the vein of Charles Tilly, which pays special attention to the mechanisms and processes that aid the study of the consistencies and explanatory principles of mobilisation (Bozarslan, 2010: 65). Thus, it is from a macro-sociological and long-term perspective that the author regards the 1940-1970s as a "period of mobilisation", owing to a "de facto alliance between the civil and military intelligentsia, the university-level and secondary-level youth and the working class" [Trans. note: "période de mobilisation... alliance de fait entre l'intelligentsia civile et militaire, la jeunesse universitaire et lycéenne et la classe ouvrière"], in contrast to the three subsequent decades of "general demobilisation" (1980-2010). The 'street' was gradually abandoned in favour of forums of dissent that were less vulnerable to state coercion, such as residential neighbourhoods or remote regions where Islamist groups and 'separatist' groups like the PKK in Turkey were being revived (Bozarslan, 2010: 69-81).

Written accounts by former activists, primarily on the left, as well as works based on oral history tend to further support this division of the time period. Indeed, several 'witnesses' to the 'revolutionary' years have actually highlighted their sense of having been swept up by an invisible force, an all-powerful and irresistible wave of energy: "We were all involved in those days" and "it was difficult not to be politicised" [Tran. note: "à cette époque, on était tous engages" ... "il était difficile de ne pas être polities"] are a few of the statements that surface regularly in interviews with former activists, as well 
as in their autobiographies (Harun, 1975; Yüksel, 1992; Oral, 2003; Mater, 2009). While such remarks may well illustrate the uncertainty and radicalisation that formed the backdrop of the period, they nonetheless create a narrative that leaves no space to consider the varying degrees of engagement amongst higher-level students or the differences in mobilisation between universities, or even between colleges within the same university. For instance, it should be noted that the involvement of many 'activists' between 1960-1970 was limited to sometimes one-off, 'acritical' participation in the protests, boycotts and sit-ins organised by 'real' leaders. As with any individual, or indeed collective, memory, what is really at play is the construction of a selective narrative that broadly aims to legitimise the choices made by the actors during and after their period of involvement.

Furthermore, as Emin Alper points out, the accounts of the various political generations connected to both the 'great demonstrations' of the university sphere and Turkey's military coups (Monceau, 2007) have become a twofold 'burden' for new generations of activists. On the one hand, comparison of the protests of 1990-2000 to the "golden age" of political engagement has given rise to a shared sense of guilt and failure among Turkish students, "incapable" of repeating the "feats" [Trans. note: "gestes"] of their elders (Alper, 2009: $\mathrm{x}$ ). On the other hand, the shadow of the "heroic" generations still hangs over the young activists of today, so much so that the " 90 s generation" - considered to be apolitical, consumerist and passive (Lüküslü, 2005) - are viewed in public opinion as their antithesis.

In this issue, we have opted to alternate between different scales of analysis - macro, meso and micro - in order to refine several findings around the process of demobilisation and the factors contributing to disengagement. Placing these different levels of inquiry in dialogue with each other allows us to consider a range of variables, such as the degree of students' engagement, multiple affiliations, organisation types, costs and rewards, repertoires of collective action and 'biographical' details.

To what degree are the dichotomies between 'mobilisation/demobilisation' and 'politicised/apolitical' relevant beyond the macro level when considering the phenomenon of activist defection? What do the most detailed analyses of meso-level trends, "which shape and support collective action over time" [Trans. note: "qui façonnent et soutiennent l'action collective dans le temps"] (McAdam, 2005: 53), and microlevel trends reveal about collective demobilisation and individual disengagement? Likewise, how does a processual analysis of disengagement help us grasp the factors (the 'why') and trajectories (the 'how') of the phenomenon? The contributions in this issue take these questions as the starting point for a double-pronged goal. First, while acknowledging the impact of repression and the undermining of political opportunity in an authoritarian or quasi-authoritarian setting, they refine understanding of the direct link, too often assumed as self-evident, between coercion and individual disengagement (Combes and Fillieule, 2011: 1047-1072). Second, based on an examination of student movements from a variety of countries and periods, the articles as a whole open the door to possibly identifying variations concerning both the degree of demobilisation of organisations and the impact of repression on groups and their activists in relation to different stages, as well as the relationship between personal resources and the costs of disengagement.

31 Certainly, the collective demobilisation of the student community in Turkey may readily be explained by a number of structural factors broadly shared by other 
countries both near and far, such as the active 'depoliticisation' policy imposed on universities by YÖK, the global decline of leftist ideologies, 'neoliberal' education reforms that have spurred increased competition between students in the 'global university' (Marginson, 2008: 87-107), the impoverishment of public universities and consequent 'desacrilisation' of their legitimacy in society, the economic troubles faced by Turkey in the 1990s, which prompted higher-level students to realign toward the centre in their personal goals, or even the 'societal fatigue' that affected many spheres of Turkish society following a period of intense mobilisation that sometimes carried a significant cost: prison, inability to obtain a college degree, exile, the physical and/or psychological after-effects of torture, etc. Lastly, we should not forget that thirty years after the coup d'état led by General Kenan Evren, the state repression executed between 1980-1983 remains a trauma in Turkey's collective memory - one that fuels the idea of activism as a dangerous activity to this day (Berrak Tuna, 2011: 69). ${ }^{12}$

However, while the establishment of YÖK unquestionably had immediate consequences for student movements generally, the collective demobilisation of the 'leftist forces' should not make us forget that Turkish universities witnessed a revival of the student sphere marked by Islamism (Güven, 2005: 205) and Kurdish nationalism towards the end of the $1980 \mathrm{~s} .{ }^{13}$ In other words, the military intervention of September 1980 gave a temporary jolt to collective action, which is understood as "any concerted action carried out by one or multiple groups seeking to achieve shared aims" [Trans. note: "toute action concertée de un ou plusieurs groupes cherchant à faire triompher des fins partagées"] (Fillieule, 1993: 9), within the university community and within all spheres of Turkish society. In the medium to long term, however, it had differing effects depending on political leaning and movement: right-wing, left-wing, Islamist or Kurdish nationalist. Furthermore, state coercion could not stifle the engagement of new generations of students (Birikim, 2011), nor the emergence of new forms of action within the student community - such as 'post-it activism' or distance activism - that were less risky and less demanding in terms of time, but still taken seriously by the Turkish government (Berrak Tuna, 2011). Thus, a more fine-grained analysis of the phenomena of demobilisation and individual disengagement is needed.

\section{Individual disengagement}

While Murat Yllmaz's contribution does, to a great extent, affirm the prominent role of repression in the collective demobilisation of leftist student communities in Turkey, Yllmaz also adds several important nuances to this point. First is that not all Turkish universities were transformed into dissident spaces in the late 1970s. Some universities stayed away almost entirely from the mass demonstrations, which should indicate the need for further research on the differing participation levels of higher education students within the same political context. Secondly, he shows how much the response to repression may vary within the same generation or political cohort. For example, while state repression certainly had biographical consequences for the activists interviewed by Yllmaz - prison, torture, temporary/permanent suspension of studies it in no way meant complete disengagement. They attempted to regroup, but faced with a highly oppressive environment and a 'new generation' of seemingly 'apolitical' students, they felt forced to overhaul their action playbook and even to abandon the university as a privileged site of resistance. 

study of the student union at Genç-Sen, a higher-level institution, shows how much continuity exists between mobilisations past and present. As such, and in the vein of Verta Taylor's study on the American women's rights movement from 1945 to the mid-1960s (Taylor, 1989: 761-775), Erdinç argues that, despite the repression that followed the coup d'état of 1980, the link between some of today's student movements and those of the 1960-1970s has never been fully broken, be it only through slogans or personal ties between new and old generations of activists. Furthermore, this continuity may contribute to disengagement if new activists view the attachment to 'old ideas' as, essentially, a roadblock to revitalising mobilisation of the student youth. Facing 'inertia', either real or imagined, potential recruits will choose to withdraw, either to seek out a new experience in a different movement or to remain among the 'apolitical masses' denounced, sometimes unfairly, by a large segment of public opinion.

But the reality is that multiple factors contribute to demobilisation, none of which is necessarily linked to the authoritarian or semi-authoritarian nature of the regime in power. Joseph Hivert's paper on Morocco's 'February 20' movement presents a compelling hypothesis: when activists are poorly dispersed and/or the capacity for collective action is low, the probability of defection increases. As such, even if activists who have chosen to 'exit' may, at first glance, give other reasons to 'justify' their disengagement - such as their demands having been met - it is the lack of biographical availability, and not necessarily the political environment, that proves the determining factor for a certain type of activist. 

striving for the autonomy of universities in Egypt, presents a very rich paradox. While traditional structural analysis of activist engagement would stress the importance of favourable conditions - notably, a democratic framework - for the development of social mobilisation, Geer's case study challenges the underlying principles of this approach by examining the structure of political opportunities. Geer shows how, in an authoritarian or semi-authoritarian environment, the movement sparked in 2004 by academics aiming to defend the autonomy of universities allowed these activists to establish themselves as a point of reference for 'pro-democracy' student bodies and intellectuals. In contrast, the same cultural and symbolic capital - reputation, recognition, popularity - lost its value in a (theoretically) more favourable setting following the fall of 'dictator' Hosni Moubarak and the start of a period of uncertainty and fluidity (Dobry, 1986) ushered in by the popular revolts in Egypt. This loss of capital led to the defection of a portion of the activists, namely university professors and lecturers, who saw the return on their engagement, whether objective or subjective, as minimal.

The revolts in the Arab world between 2010 and 2011, the 'indignados' movement in Spain, 'Occupy Wall Street' in New York and the 'resistance' in Istanbul's Gezi Park have once again reminded researchers that mass demonstrations and dissidence are topics worthy of study, as the number of publications and conferences dedicated to them attests. Beyond this, does the revival of student demonstrations in Egyptian universities in 2013 - or the protests of students of the Middle East Technical University in Ankara against the construction of a motorway threatening to destroy a large swathe of their tree-lined campus - herald the return of the university as a bastion of protest in the Middle East (Akyol, 2013; Hamed, 2013; Mohammed, 2013)? It is, of course, still too early to answer such a question. For now, it would seem that while the university is again $a$ space of dissidence, it is not the privileged site of protest in these countries. Whatever the case, and somewhat against the tide, this issue hopes to have contributed to the understanding of demobilisation and disengagement as phenomena through examination of the student community, highlighting once again that both of these are, in spite of everything, an ingrained part of social movements and social mobilisation.

\section{BIBLIOGRAPHY}

Abadan, Nermin (1963). 'Values and Political Behaviour of Turkish Youth', in The Turkish Yearbook of International Relations IV, Institute of International Relations Faculty of Political Science, Ankara, University of Ankara.

Abdalla, Ahmad (1985). The Student Movement and National Politics in Egypt, 1923-1973, London, Al Saqi Books.

Akyol, Mustafa (2013). 'Why Turks are fighting over trees', Al-Monitor, 24 October, URL: http:// www.al-monitor.com/pulse/originals/2013/10/ankara-highway-project-uproots-trees.html 
Alper, Emin (2009). Student Movement in Turkey from a Global Perspective, Unpublished doctoral thesis, Bogaziçi University, Istanbul.

Alper, Emin (2010). ‘1968: Global or Local?', Red Thread, No. 2. URL: http://www.red-thread.org/ en/article.asp? $\mathrm{a}=38$

Ateş, Toktamış (1984). Niçin YÖK değil, Istanbul, Süreç.

Aydınoğlu, Ergun (2011) Türkiye solu (1960-1980), Istanbul, Versus Yayınları.

Aypay, Ahmet (2003). 'The relationship between state and higher education: The case of Mulkiye College in Turkey', Mediterranean Journal of Educational Studies, 8 (2), pp. 109-135.

Bashkin, Orit (2009). The Other Iraq. Pluralism and Culture in Hashemite Iraq, Stanford, Stanford University Press.

Bayat, Asef (2010). Life as Politics: how ordinary people change the Middle East, Stanford, Stanford University Press.

Bayat, Asef (2011) 'Reclaiming Youthfulness', in S. Khalaf and R. S. Khalaf (eds.), Arab Youth, Social Mobilisation in Times of Risk, London, Saqi Books.

Becker, Howard (1985). Outsiders. Études de sociologie de la déviance, Paris, Métailié.

Bilgin, Fevzi (2013). Turkey: Politics of the Gezi Protests, Washington DC, Rethink Brief, Rethink Institute.

Birikim (2011). Öğrenci hareketi nereden nereye?, April-May, n² 264-265, 152 pages.

Björgo, Tore and Horgan, John (eds.) (2009) Leaving Terrorism Behind. Individual and Collective Disengagement, London, Routledge.

Bourdieu, Pierre (2002) Questions de sociologie, Paris, Les éditions de Minuit.

Bozarslan, Hamit (2010). Sociologie politique du Moyen-Orient, Paris, La Découverte.

Bozarslan, Hamit et al. (2011). Passions révolutionnaires. Amérique latine, Moyen-Orient, Inde, Paris, EHESS.

Bucholtz, Mary (2002). 'Youth and Cultural Practice', Annual Review of Anthropology, vol. 31, pp. 525-552.

Braungart, Richard G. and Braungart, Margaret M. (1993). Life course and generational politics, Lanham, University Press of America.

Can, Kemal (2000). 'Youth, Turkism and the Extreme Right: The Idealist Hearths', in S. Yerasimos, G. Seufert and K. Vorhoff (eds.), Civil Society in the Grip of Nationalism: Studies on Political Culture in Contemporary Turkey, Istanbul, Orient-Institut, pp. 335-373.

Combes, Hélène and Fillieule, Olivier (2011). 'De la répression considérée dans ses rapports à l'activité protestataire', Revue française de science politique, 61 (6), pp. 1047-1072.

Corrigall-Brown, Catherine (2012). Patterns of protest: trajectories of participation in social movements, Stanford, Stanford University Press.

Crossley, Nick (2008). 'Social networks and student activism: on the politicising effect of campus connections’, The Sociological Review, 56 (1), pp. 19-38.

Dinç, Güney (1986). YÖK çıkmaıi. Yükseköğretim davaları, Istanbul, Bilim ve sanat.

Dirks, Sabine (1975). Islam et jeunesse en Turquie aujourd'hui, Thesis presented at Paris V, Paris. 
Duboc, Marie (2010). 'Egyptian leftist intellectuals' activism from the margins. Overcoming the mobilization/demobilization dichotomy', in J. Beinin and F. Vairel (eds.), Social movements, mobilization, and contestation in the Middle East and North Africa, Stanford, Stanford University Press, pp. 61-79.

Duclert, Vincent (2010). L'Europe a-t-elle besoin des intellectuels turcs?, Paris, Armand Colin.

Dobry, Michel (1986). Sociologie des crises politiques. La dynamique des mobilisations sectorielles, Paris, PUF.

Farag, Iman (2007). 'Quand l'éducation forme la jeunesse : la construction d'une catégorie en Égypte', in M. Bennani-Chraïbi and I. Farag (eds.), Jeunesses des sociétés arabes par de-là les promesses et les menaces, Le Caire, CEDEJ, pp. 49-78.

Fayart, Jean-François (2008). La politique par le bas en Afrique noire, Paris, Karthala.

Feyizoğlu, Turhan (2002). FKF. Fikir Kulüpleri Federasyonu : Demokrasi Mücadelesinde Sosyalist Bir Öğrenci Hareketi, Istanbul, Ozan Yayıncılık.

Fillieule, Olivier and Péchu, Cécile (1993). Lutter ensemble. Les théories de l'action collective, Paris, L'Harmattan.

Fillieule, Olivier (2001). 'Propositions pour une analyse processuelle de l'engagement individuel', Revue française de science politique, 51 (1-2), pp. 199-215.

Fillieule, Olivier (ed.) (2005). Le désengagement militant, Paris, Belin.

Fillieule, Olivier (2013). 'Postface. Des marées aux inondations', in A. Allal and T. Pierret (eds.), Au cour des révoltes arabes, Paris, Armand Colin, pp. 287-308.

Fuchs-Ebaugh, Helen Rose (1988). Becoming an Ex: The Process of Role Exit, Chicago, University of Chicago Press.

Girardot, Clément (2013). 'Des campus aux prisons turques', Amnesty, May, pp. 28-30.

Gökay, Bülent and Xypolia, Ilia (eds.) (2013). Reflections on Taksim-Gezi Park Protests in Turkey, Keele, Keele European Research Centre.

Gourisse, Benjamin (2010). L'État en jeu. Captation des ressources et désobjectivation de l'État en Turquie (1975-1980), Unpublished thesis, Sorbonne University (Paris-1).

Guiter, Laurent (1997). 'L'Université : histoire d'une normalisation', Cahiers de l'Orient, nº 46, pp. 93-101.

Güven, Ismail (2005). 'The impact of political Islam on education: the revitalization of Islamic education in the Turkish educational setting', International Journal of Educational Development, vol. 25, pp. 193-208.

Haggai, Erlich (1989). Students and University in 20th Century in Egyptian Politics, London, Frank Cass.

Hamed, Enas (2013). 'Egypt's students fuel anti-government protests', Al-Monitor, 22 November, URL: http://www.al-monitor.com/pulse/originals/2013/11/egypt-student-movements-fuelprotests.html

Harun, Karadeniz (1975). Olaylı Yillar ve Genclik, Istanbul, May Yayınları.

Hirschman, Albert O. (1983). Bonheur privé, action publique, Paris, Fayard.

Kemal, Mustafa (1989). Nutuk, Ankara, Türk Tarih Kurumu Basımevi.

Kongar, Emre and Küçükkaya, Aykut (2013). Gezi Direnisi (Türkiye'yi sarsan otuz gün - Artık hiçbir şey eskisi gibi olmayacak), Istanbul, Cumhuriyet Kitapları. 
Lüküslü, Demet (2005). 'Constructors and constructed: youth as a political actor in modernising Turkey’, in J. Forbrig (dir.), Revisiting youth political participation, Strasbourg Council of Europe, pp. 29-35.

El Khawaga, Dina (2003). 'La génération seventies en Égypte. La société civile comme répertoire d'action alternatif' in M. Bennani-Chraïbi and O. Fillieule (eds.) Résistance et protestations dans les sociétés musulmanes, Paris, Sciences Po, pp. 271-292.

McAdam, Doug (2005). 'Pour dépasser l'analyse structurelle de l'engagement militant', in O. Filliuele (dir.), Le désengagement militant, Paris, Belin.

Mauger, Gérard (2010). 'Jeunesse : essai de construction d'un objet', Agora débats, nº 56, pp. 9-24.

McAdam, Doug (1988). Freedom Summer, New York/Oxford, Oxford University Press.

Mardin, şerif (1977). 'Youth and Violence in Turkey', International Social Science Journal, 1 (2), pp. 229-254.

Marginson, Simon (2008). 'Vers une hégémonie de l'université globale', Critique internationale, $\mathrm{n}^{\circ} 39$, pp. 87-107.

Massicard, Élise (2010). 'Répression et changement des formes de militantisme : carrières de remobilisation à gauche après 1980 en Turquie', Sociétés politiques comparées, $\mathrm{n}^{\circ}$ 28, pp. 1-18.

Mater, Nadire (2009). Sokak güzeldir: 68'de ne oldu?, Istanbul, Metis Yayınları.

Mohammed, Adbel Salam (2013). 'Egyptian universities between the Brotherhood and the military', Sada, 20 December, URL: http://carnegieendowment.org/sada/2013/12/20/egyptianuniversities-between-brotherhood-and-military/gwty

Monceau, Nicolas (2005). 'La politique de l'éducation nationale en Turquie. Bilan de l'action du gouvernement AKP (2002-2004)’, Outre-Terre, n 10, pp. 129-142.

Monceau, Nicolas (2007). Générations démocrates. Les élites turques et le pouvoir, Paris, Dalloz.

Mutlu Ulus, Özgür (2011). The Army and the Radical Left in Turkey, New York, I.B. Tauris.

Neyzi, Leyla (2001). 'Object or subject? The paradox of youth in Turkey', International Journal of Middle East Studies, 33 (3), pp. 411-432.

Oral, Çalışlar (2003). '68 Anılarım, Istanbul, Gendaş.

Ozankaya, Özer (1978). Türk Devrimci ve Yüksek Öğretim Gençliği, Ankara, SBF Yayınları.

Özbank, Murat (2013). Gezi Ruhu ve Politik Teori, Istanbul, Kolektif Kitap.

Récappé, Bénédicte (2009). 'Mobilisation étudiante et génération politique : qui précède l'autre ? Réflexions comparatives à partir des exemples hongrois (1956) et mexicain (1968)', Revue internationale de politique comparée, 16 (2), pp. 205-220.

Rey, Matthieu (2010). 'La Wathba : Manifester en Irak en 1948', Vingtième siècle, nº 108 (OctoberDecember), pp. 25-37.

Samim, Ahmet (1981). 'The Tragedy of the Turkish Left', New Left Review, I/126, pp. 60-85.

Scott, James C. (1985). Weapons of the weak: everyday forms of peasant resistance, Yale, Yale University press.

Scott, James C. (1990). Domination and the arts of resistance: hidden transcripts, Yale, Yale University Press. 
Şeni, Nora (2007). 'La jeunesse, une non-génération. Rhétorique éducative dans la Turquie des années trente', in F. Georgeon and K. Kreiser (eds.) Enfance et jeunesse dans le monde musulman, Paris, Maisonneuve \& Larose, pp. 233-257.

şimşek, şaban (2006). Kırmızı çizgi YÖK, Ankara, Nobel Yayın Dağıtım.

Szyliowicz, Joseph S. (1973). Education and Modernization in the Middle East, Ithaca-London, Cornell University Press.

Taylor, Verta (1989). ‘Social movement continuity: The women's movement in abeyance', American Sociological Review, 54 (5), pp. 761-775.

Tilly, Charles (2003). The Politics of Collective Violence, Cambridge, Cambridge University Press.

Tuna, Yasemin Berrak (2011). Internet et militantisme ni utopie ni dystopie : Usage de nouvelles technologies d'une association contestataire en Turquie, unpublished degree thesis (Paris-I).

Turan, Ilan (2010). ‘University Governance in Turkey', in C. Kerslake, K. Öktem and P. Robins (eds.), Turkey's Engagement with Modernity. Conflict and Change in the Twentieth Century, New York London, Palgrave Macmillan, pp. 143-164.

Üstel, Füsün (1994). 'Synthèse turco-islamique entre traditionalisme et modernité', in J. Thobie and S. Kançal (eds.), Industrialisation, communication et rapports sociaux en Turquie et en Méditerranée orientale, Paris, L'Harmattan, pp. 387-400.

Watenpaugh, Keith (2002). 'Steel shirts, white badges and the last qabaday: Fascism, urban violence and civic identity in Aleppo under French rule', in N. Méouchy (ed.), France, Syrie et Liban (1918-1946). Les ambiguités et les dynamiques de la relation mandataire, Damas, Institut Français d'Etudes Arabes de Damas, pp. 325-347.

Wyn, Johanna and White, Robert (1997). Rethinking Youth, London, Sage Publications.

Yıldırım, Umut and Navaro-Yashin, Yael (2013). ‘An Impromptu Uprising: Ethnographic Reflections on the Gezi Park Protests in Turkey', Cultural Anthropology Online, URL: http:// www.culanth.org/fieldsights/391-an-impromptu-uprising-ethnographic-reflections-on-the-gezipark-protests-in-turkey

Yılmaz, Murat (2012). 'Le YÖK et le politique : un rapport paralysant la réforme de l'enseignement supérieur en Turquie', nº 83, pp. 153-168. DOI: 10.3917/come.083.0153

Yüksel, Baştunç (1992). şu ‘68 Kuşağı, Istanbul, Yılmaz Yayınları.

\section{NOTES}

1. The Gezi demonstrations opposed the pedestrianisation of Taksim Square, the demolition of Gezi Park and the construction, in its place, of a replica Ottoman military barracks containing a shopping centre and a mosque.

2. For analyses written during the protests, see the blog of the IFEA [Trans. note: the French Institute for Anatolian Studies] (http://ovipot.hypotheses.org/page/2) and Jadaliyya-Turkey (http://turkey.jadaliyya.com/).

3. Between June 6 and 7, 2013, the private company KONDA conducted a second survey of 4,411 participants, which produced similar results (Kongar and Küçükkaya, 2013).

4. Alongside the semantic sense of the term "event", Bénédicte Récappée echoes Paul Ricoeur, for whom "not everything that happens is an event" [Trans. note: "tout ce qui arrive ne fait pas événement"] when she writes that "the importance of the way in which facts are perceived 
reminds us of the constructed nature of the event, from perception to recounting, from interpretation to transmission" [Trans. note: "l'importance de la façon dont les faits sont perçus nous rappelle le caractère construit de l'événement, de sa perception à son récit, de son interprétation à sa transmission"] (Récappé, 2009: 210).

5. Thus, for example, Fadhil Abbas al Mahdawi, presidential court judge under d'Abdul Karim Kassem in Iraq, declared that: "Students all over the world are soldiers of science, literature and arts, which are the essential elements of building nations and bringing progress to countries [...]. Besides students are always soldiers of justice, democracy, liberty and peace”. Hoover Institution Archives, U.S.N.S.A, Box 221. "L'étudiant irakien", published by the Fédération générale d'étudiants dans la République irakienne, $\mathrm{n}^{\circ} 1$, June 1959, p. 3.

6. Following the Second World War, new universities sprang up very rapidly all across the Middle-East: Egypt (1942, 1949, 1950), Syria (1946), Lebanon (1950), Libya (1955), Iraq (1956), Morocco (1957), Saudi Arabia (1957), Tunisia (1958), Jordan (1962) and Kuwait (1966). While the academic year 1961-1962 saw 157,00 students spread across the 20 universities then operating in the Arab world, ten years later, 48 universities took in more than 375,000 higher-level students.

7. The category of 'youth' does not refer to a distinct social unit, and thus, cannot be considered a homogeneous category (Bourdieu, 2002). Furthermore, as historians and anthropologists of the concept point out, 'youth' is a social construct whose definition and attributes vary according to its historical and socio-economic context. In this sense, the Turkish 'youth' of the 1960-1970s, with its 'modern' practices (leisure time, easy access to public transport, dress codes, etc) and language codes, was limited almost exclusively to students and urban youth (Bayat, 2011; Wyn and White, 1997; Bucholtz, 2002: 525-552; Farag, 2007: 49-78; Mauger, 2010: 9-24).

8. While right-wing students were trained in the 'foyers idéalistes' (Can, 2000: 335-373), training of activists on the left tended to take place on university grounds and in student dormitories. Notable among the left-wing student unions from 1964 onwards were the Thought Clubs (Fikir Kulüpleri), which became the Revolutionary Youth Organisation (Türkiye Devrim Gençlik Teşkilatı or Dev-Genç) in 1969 (Feyizoğlu, 2002).

9. The mass demonstrations of the 1960-1970s should not blind us to the fact that, despite the image portrayed in the memoirs of old activists and by the newspapers of the time, the majority of students did not belong to a student union. Hence, according to a survey carried out in 1955 at Ankara University, $78.2 \%$ of respondents were not registered with any student organisation, $19 \%$ were members of a non-political student organisation and 3.8\% were part of a political student organisation (Dirks, 1975: 261). Similarly, while there is proof of some student involvement in armed combat groups, it was still a rare phenomenon. The engagement level of 'politicised' students varied greatly and should not be overestimated.

10. Deniz Gezmiş was the leader of the People's Liberation Army of Turkey (THKO). Other similar groups included the Workers and Peasants Liberation Army of Turkey (TIKKO) and the People's Liberation Party-Front of Turkey (THKP).

11. The Turko-Islamic synthesis, as an underpinning ideology of Turkish politics since 1980, was nothing new in terms of the intertwining of Islam and Turkism. Developed in the "Turkish salons" of the mid-20th century, it was applied in practice following the military coup of 1980, and was particularly present in the spirit of the constitution of 1982, which introduced 'authoritarian democracy', an end to the autonomy of universities, the formation of State Security Courts and a centralised administrative system (Üstel, 1994: 387-400).

12. A perception that is by no means inaccurate. Activism in Turkey remains a risky choice, as proven by the waves of arrests that followed the evacuation of Gezi Park in July 2013. More broadly, it is notable that Turkey has been condemned by the European Court of Human Rights on several occasions for failing to respect freedom of expression and for abuses committed against activists in detention. In the student community alone, the Initiative for Solidarity with 
Incarcerated Students (TÖDI) has documented around eight hundred students behind bars, awaiting trial or serving a sentence, of whom ninety percent are Kurds (Girardot, 2013: 29).

13. Through my 2013 survey of students who had attended Dicle University in Diyarbakır between 1986 and 1990, I was able to conclude that the student movement in this majority Kurdish city was a reality. Yet, unlike in the late 1970s, ethnic claims within the student movement became hegemonic, to the detriment of groupings aligned with the Turkish left.

14. Howard Becker (Becker, 1985) expanded the concept of the career, in the sense of profession, to include different manifestations of engagement. The idea of an 'activist career', subsequently adopted by other researchers within the sociology of mobilisations (Filleule, 2001: 199-217), is desirable in that it emphasises the processual aspect of activist trajectories as well as the interconnectedness between individual stories and the broader situational context.

\section{ABSTRACTS}

The uprisings that erupted unexpectedly in the Middle East between 2010 and 2011 propelled the region's youth to the forefront of the political and media spheres. According to some scholars, we are witnessing a re-politicisation of Middle Eastern youth, a marked contrast to their 'depoliticisation' and 'apathy' as a group in recent years. Yet, although the youth (incidentally, the majority of the population in the region) have unquestionably participated in popular protests, student unions seem not to have played a role thus far. From a macro-level perspective, the marginal role of student associations may seem natural; whilst nationalist and revolutionary leaders encouraged students to actively participate in politics 'for the sake of the nation' until the 1960s, both revolutionary and conservative regimes progressively sought to 'depoliticize' them. This turned higher education into a privileged 'sandbox' for testing methods of repression which would then be extended to all segments of society. However, while scholars should consider the political context of a given society, namely, the authoritarian or semi-authoritarian regimes of most Middle Eastern countries, we must ask: what can meso- and micro-level analysis reveal about the complex and multi-layered phenomena of collective demobilization and individual disengagement? This special issue offers some responses to that central question, analysing different case studies within higher education, from Turkey and Egypt to Morocco and Mexico, over the last forty years.

\section{INDEX}

Keywords: demobilization, disengagement, militant trajectories, repression, higher education

\section{AUTHORS}

\section{JORDI TEJEL GORGAS}

Research professor of International History at the Graduate Institute of International and Development Studies, Geneva 